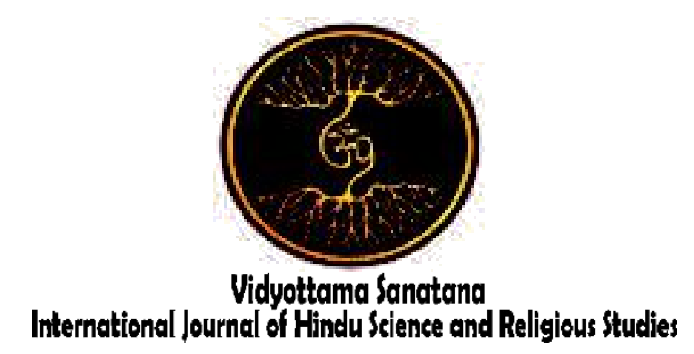

Vol. 3 No. 2 October 2019

\title{
MYSTICISM OF BARONG AND RANGDA IN HINDU RELIGION
}

\author{
By: \\ Susilo Edi Purwanto \\ STAHN Gde Pudja Mataram \\ E-mail : susiloedipurwanto@ stahn-gdepudja.ac.id
}

Received: July 21, 2019

Accepted: September 28, 2019

Published: October 31, 2019

\begin{abstract}
Barong and Rangda have become part of culture and religion in the tradition of Hindu religion. The Barong and Rangda tradition is a ritual process or pratima that is very sacred. The scary forms of both often scare children, but is greatly admired and adored since it is considered a protector from danger and disaster. If Barong and Rangda are worshiped inhorrifying figures, it is then not uncommon for non-Hindus to assume that Hindus worship Satan because their description of Satan relates to scary things. Based on the above, there are three essential points to focus in this article. First, how the concepts of Barong and Rangda are in Hindu Literature; second, how Barong and Rangda are in Balinese Culture; and third, how the religious system of Barong and Rangda is in Hindu rituals. In analyzing these three topics, the researcher applied qualitative method to explain Hindu literary sources based on religious theory. The Barong and Rangda conception is in the Hindu literature, namely the Purana books and the books that have been adapted in Old Javanese literature. In the Purana books, Barong and Rangda can be associated with the manifestation of Shiva and Durga in the aspect of Krodha. Second, Balinese culture sets Barong and Rangda in the Sacred and Profane realms. Barong and Rangda become Wali Dance during religious rituals. Third, the Hindu Religious System explains that Barong and Rangda is the concept of Shivaistic divine teachings which explains the dualistic aspects of God as Purusa and Prakerti as a whole unit.
\end{abstract}

Keywords: Mysticism, Barong, Rangda, Hindu Religion 


\section{INTRODUCTION}

Mysticism is a subsystem that exists in every religion to fulfill human desire to experience and feel emotions of being united with God. Mysticism is related to a teaching which states that there are things humans cannot reach (Tim Penyusun, 2011: 921). Mystical things in Hinduism are contained in the system of dogma concerning many theological aspects which have become religious experiences to the worshipers.

The beginning of the Hindu worship system was illustrated through the religious activities of the Dravidas in India at 3500 BC with important features as follows; (1) Worship of the Mother Goddess, which is a worship of the power of women (shakti) as the source of all creations; (2) Worship of the God Purusha (Male God), who is worshiped along with the Mother Goddess; (3) Worship of Lingga (Ithy-Phallicism), which is a worship towards the god aspect through the stone in the form of male genitals (phallus); (4) Worship of trees and animals; (5) Worship towards Statues or Arcā (Iconism); and (6) Sacrificial Ceremony.

The arrival of the Aryan in India brought with it the early Vedic civilization and developed into a complete vedic religion with Catur Veda as its main reference. The Vedic Period lasted around 2000 BC to 1000 $\mathrm{BC}$. The characteristics of this Vedic religion include believing in many gods and also in the One God, believing in the ancestors, the importance of reading the Vedic holy book, the importance of carrying out the Yajna sacrificial ceremonies, the importance of carrying out death ceremonies, the importance of the priest's position, not worshiping statues, not making place of worship, an optimistic religion, a religion of taste, a religion of satisfaction, and moksa which can be achieved through Yajna.

After the Vedic Period, Hinduism developed into a system of the Brahman Age which lasted around $1000 \mathrm{BC}$ to $300 \mathrm{AD}$. Hinduism experienced a period of glory, setback and resurrection, marked by the nonallowance of Catur Veda to be read to the public. As a result, the books of Pancama
Veda, Itihasa and Purana were written as a substitute. The following things occured afterwards; the worship of Tri Murti; Brahma, Vishnu, and Shiva, the emergence of Sad Darsana, the writing of Vedic Khila, the emergence of Stotra, Stuti, and Stawa, the emergence of the book Kalpasutra, all local customs must be carried out, and the emergence of calculations of yuga.

The most significant point of India's relations with Indonesia occurred at the end of the Brahmin era and the Purana era which developed around the year $300 \mathrm{AD}$ to 700 AD. At suchperiod in India, according to Palgunadhi (2013: 45), there were 18 general characteristics, i.e., (1) the emergence of many sects, and sometimes often in conflict; (2) the Vaishnavas taking over the Buddhist teachings; (3) the development of the teachings of Tantrayana; (4) The Purana books recognized as Pancama Veda; (5) the emergence of a place of worship (temple); (6) the emergence of statue worship (arcanam); (7) the conflict between the vegetarians and non-vegetarians; (8) Catur Varna was started to be strongly understood as inheritance or descent; (9) the emergence of the pariah caste in India; (10) the commencement of the teachings of Catur Asrama done in a disciplined manner; (11) the commencement of large ceremonies; (12) the emergence of calculations about the Vedic Age; (13) the emergence of the worship of Awatara Vishnu; (14) the worship of 33,000,000 gods (33 lakh); (15) the appearance of a Hindu religious celebration; (16) the worship of Panca yatana; (17) the priest getting an important position; and (18) customary law being equated with religious law.

The development of the Hindu Kingdoms in Indonesia also marked the development of Hinduism which was quite dynamic, both religiously and culturally. The development of sects in India was brought along to Indonesia and was glued with thick local religious traditions, so that Shivaism, Buddhism, Vaishnavaism and others obtained their respective positions. As revealed by Mulyana (2005: 90), there was a 
system of government during the Majapahit Kingdom era which wasin charge especially of religious issues, namely Dharmmadhyaksa. There were two Dharmmadhyaksa in the Majapahit Kingdom; Dharmadhyaksa ring kasewan which was Shiva religion dignitary and the Dharmadhyaksa ring kasogatan which was a Buddhist dignitary.

For the purpose of worship (Bhakti and Krama Marga), the concept of Hindu deity has evolved with the emergence of depictions of God in the form of idol gods (istadevata). Istadevata is a god who is loved and admired according to one's profession since it is believed to always provide protection. Ramacandra (in Titib, 2001: 38) mentions that there are several concepts of Istadevata, including Citradevata (a god who is sculptured and engraved), Gramadevata (idol god of the village community), Kuladevata (family god), Upadisadevata (arca of god given by the guru), Uddhisthadevata (god worshiped on certain days), and Thirtadevata (god in a certain place). This Istadevata concept shows that the Hindu deity is polytheistic because it is manifested in religious symbols, both in the form of banten and sacred buildings (palinggih). One of the Istadevata worshiped by Hindus in Bali in the form of Citradevata is Barong and Rangda.

Barong and Rangda have become part of culture and religion in Hinduism. In the religious aspects, Barong and Rangda are very sacred Pratima. The scary form of these two Pratima often scares children, but is greatly admired and adored since it is considered a protector of danger and disaster. If Barong and Rangda are worshiped in such horrifying forms, it is then not uncommon for non-Hindus to think that the Hindus worship Satan, because their description of Satan relates to scary things.

In the cultural aspect, Barong and Rangda are not just worshiped Pratima, but also an amazing artwork of the Hindus in Bali. These artworks are usually performed at a ceremony in a temple, combined with Calonarang play. The performance was held at Pura Dalem which was close to setra, showing magical power for those who watch it. The beauty of Barong and Rangda artworks not only amazes local art connoisseurs, but also foreign tourists. Hence, the mystical Barong and Rangda are very interesting to be studied more deeply regarding their conceptions religiously or culturally.

Based on this background, there are three main issues to be revealed. 1) How are the concepts of Barong and Rangda in Hindu Literature?; 2) How are Barong and Rangda in Balinese Culture?; and 3) How are Barong and Rangda in the Hindu Religious System?

\section{LITERATURE REVIEW}

Hinduism has generated many concepts about religious and cultural systems. Barong and Rangda are not just cultural expressions without meaning in Hinduism, but it is based on Tattwa which is practiced in Susila and religious ceremonies. This is interesting to analyze more in depth about its underlying aspects. Therefore, it is important to position this research from other studies in the form of books, journals, papers, and other research as summarized in the following literature review.

Dana (2011) in his study entitled "Paruman Barong di Pura Puncak Padang Dawa Baturiti Tabanan Persepektif Kajian Budaya" describes that Paruman Barong is ameeting ritual of Barong from various regions of Central and South Bali. In this paruman Barong, the penyungsung arrived at Puncak Padang Dawa Temple with their respective cultural traditions. Cultural integration occurs through paruman in the Puncak Padang Dawa.

That study explained various types of Barong from Central and South Bali in a joint ritual. This is a basic study material to see the religious conception of Hindus in Bali. The difference lies in the religious aspect that was tried to be revealed in this study. The researcher tried to trace the basic conceptions in the teachings of Hinduism.

Segara (2000), in his book entitled "Mengenal Barong dan Rangda" discusses 
the origins, types, and symbolic meanings of Barong and Rangda. This research also has not far traced the concepts of Barong and Rangda in the context of comprehensive religious studies. The researcher wanted to proceed by tracing the theological references of Barong and Rangda so as to make clear the dark side of the understanding of Pratima in these scary forms.

Swadiana (2008), in his book entitled "Barong Landung: Bernuansa Magis dan Religius" is a study based on personal experience about one of the religious cultures in Bali. Barong Landung is thought to be a cultural expression and religious appreciation, especially in Pura Dalem Balingkang which is associated with the mythology of Dalem Balingkang Jayapangus with Kang Cing Wei. This religious tradition is interpreted as a cultural phenomenon coming from human creativitiy, unlike this research which focuses more on the theological aspects in Hindu religion.

Segara (2018) in the Analysis of Journal of Social Science and Religion entitled "Hindu Spiritual Groups in Indonesia and Their Active Roles in Maintaining Harmony" depicts diverse thoughts in Hinduism. There are differences in religious practices in Hinduism in spiritual groups which always happens from era to era. Such differences have become the basis of diversity of understanding of theology in Hinduism. The researcher also made such basis a benchmark for thinking about theological concepts in the concepts of Barong and Rangda.

Santika (1987), in her dissertation entitled "Kedudukan Bhatari Durga di Jawa pada Abad X $-X V$ Masehi" revealed the position of Bhatari Durga in the Hindu concept as the most important goddess in Shiva and Skata religion. Durga has various aspects that are often discussed in the Purana and Tantra books as an asura destroyer, as the ruler of plants and fertility, and as the ruler of infectious diseases. In Java, Durgais known in only two aspects, i.e., as the destroyer of asura and the ruler of disease. Durga as the ruler of infectious diseases was only found in the Calonarang book, while
Durga as a giant destroyer was found in inscriptions and kekawin.

The above research only examines one feminine aspect in Hindu theological systems, while masculine aspects of it have not been discussed much. In the context of the Shivaistic, both aspects are important because both are one entity. For this reason, Santiko's research can be used as a reference to enrich only one feminine aspect.

\section{RESEARCH METHOD}

A method describes how data is managed as the basis of research. This article is a field research on the phenomenon of Hindu religious significance in Bali. This qualitative research is based on the shift in meaning of religious traditions from sacred to profane. The shift from the sacred to the profane is done due to the needs of tourism in Bali. Such shift from sacred to profane called for a library data search for Hindu teachings originating from Hindu scriptures that are relevant to the concept.

This research can be classified into studies of religions. Suprayoga and Tobrani (2001: 17) describe that academic studies of teachings and diversity can be viewed from the research object which can be classified into three, namely (1) teachings, (2) diversity, and (3) the structure and dynamics of the religious community. To understand and explain research on religion, various approaches can be used, but for empirical objects such as Barong and Rangda conceptions in Hinduism.

Bali was chosen as a location to conduct research due to several reasons. First, Bali has become the center of the latest development of Hinduism after the collapse of Majapahit Kingdom. Second, research data on Barong and Rangda is more common in Bali. Third, easy and affordable access.

To obtain maximum results in revealing the mysticism of Barong and Rangda in Culture and Religion of Hinduism, a few theories of Religion are used to dissect it, including Edward B. Tylor's theory of human consciousness regarding the concept of the soul, Andrew Lang's theory of the supreme 
deity, Wilhelm Schmidt's Theory of the words of God, Marett's Theory of extraordinary power. Human religion is originated from an "emotion" or a "mental vibration" which emerges from human admiration for certain things and symptoms that are extraordinary, A.C Kruyt's concept of animism and dynamism, Rudolf Otto's theory on the fear of being fascinated by the occult, and W. Robertson Smith's Theory of offering ceremonies (Koentjaraningrat, 2005: 194-201).

\section{CONCEPTUAL FRAMEWORK Mysticism of Barong and Rangda}

Mysticism is a subsystem that exists in every religion to fulfill the human desire to experience and feel emotions of being united with God. Mystic is related to a teaching that states that there are things humans cannot reach (Tim, 2011: 921). The word mysticism comes from Greek language, namely mystêriondari mystês which means an initiation in a number of mysteries or secrets about a reality of truth (Sabri, Muhammad, 2010: 1). Furthermore, the definitions of mystic include (1) Believing that the reality of absolute truth cannot be achieved through ordinary experience or intellectual, but it can only be achieved through mystical experience or non-rational paths, namely mystic institute; (2) Non-rational which is not an ordinary experience of all open realities. Mysticism believes that rational knowledge emphasizes differentiation, division, and even distortion of reality.

In the Indonesian Language Dictionary (2011: 921), mysticism is interpreted as a teaching that states that there are things that human reason cannot reach. This is usually attributed with myths; the story of group of gods and heroes of ancient times, containing interpretations of the origins of the universe, humans and the race, and containing profound meanings revealed in an occult way.

Barong and Rangda are the Pratima worshiped by Hindus as religious representations of the Gods. The etymology of the word Barong originates from the sanskrit word $b(h)$ arwang which is aligned with the word Bear. Bears are four-legged animals living in Asia, America and Europe (Segara, 2000: 7). While the word Rangda is thought to originate from the ancient Javanese language, Randa. Randa is interpreted as a widow. However, in the Hindu teachings Barong and Rangda are a manifestation of the dualistic theological aspect of the existence of God. Dualistic, different yet in pair, is God in the Masculine and the Feminine Aspects. The horrible manifestations of both are expressions of the ultimate omnipotence of God in krura aspect.

Thus in this study the aspects of mysticism in Barong and Rangda are the teachings which state that there are things unreachable by human reason about Barong and Rangda that are worshiped by the Hindus in Bali.

\section{Culture and Religion of Hinduism}

Culture comes from a Sanskrit word buddhayah, which is the plural form of buddhi (mind or reason), interpreted as things relating to mind and human reason. In English, the word 'culture' comes from the Latin word Colere, which means processing or working, or cultivating land or farming. The word culture is also sometimes translated as "Kultur" in Indonesian.

According to Koeantjaraningrat (2009: 164) there are seven elements of universal culture which includelanguage, knowledge systems, technology systems, and equipment, art systems, livelihood systems, religious systems, kinship systems, and community organizations.

Meanwhile, the word religion is defined as a system consisting of concepts that are trusted and become the absolute belief of a person and ceremonies and the leaders who carry it out. Such belief is based on the experience of human activities concerned with religion, namely a vibration of the soul, which is commonly called religious emotion (Koentjaraningrat, 2009: 295).

Furthermore, Koentjaraningrat (2009: 295) said that religious emotions are a 
phenomenon experienced by every human being. This encourages everyone to take religious actions. Maintenance of religious emotions becomes very important as part of the religious system along with three other elements, namely the belief system, the ceremonial system, and the people who adhere to that religion. These four elements are the main characteristics of religious elements.

The belief system specifically contains many sub-elements, such as the conception of good and evil gods, the nature and signs of gods, the conception of spirits as well as good and evil ancestral spirits, the conception of the supreme deity and creator of nature, the creation of the world and nature or cosmogony, problems regarding the shape and nature of the world and nature or cosmology, conception of life and death, conception of the spirit world, the afterlife, and so on. This is also added with a system of beliefs and ideas, lessons, rules, religion, holy tales about the history of gods or mythology, which are usually collected in books that are considered sacred literature. The religious ceremonial system specifically concerns four aspects, namely the place of religious ceremonies, the times when religious ceremonies are carried out, objects, ceremonial instruments, people who perform the ceremony and ceremonial leaders. The ceremony has many elements, including offering, sacrificing, praying, eating together which has been purified with prayer, dancing sacred dances, singing holy songs, procession or parade, playing holy drama, fasting, intoxication or blurring the mind with drugs until possessed or drunk, meditating, etc. (Koentjaraningrat, 2009: 296).

It is further explained regarding the people who adhere to religion that it in particular concerns with the relationship between one follower and another, and the relationship with the religious leaders, both at the ceremony and in everyday life. This shows that there is an order in religious life which is regulated through the organization regarding its rights and obligations.
This is in line with what was said by Hardjana (2005: 50-52) that religion is an appreciation of awareness of the relationships and bonding back to God. The essence of religion is religiosity manifested into four main elements through a system of dogmas, doctrines or teachings, worship or cults, morals or ethics, and institutions or organizations. Religious dogma formulates the nature of God that is known, experienced, trusted, and His will for humans and the world. Religious rituals determine the proper way for structuring human relations with God, such as the place and time the relationship is held and the ways and forms of human relations with God are held. Religious moral outlines behavioral guidelines, namely guidelines that establish appropriate or inappropriate behaviors in relation with experience and belief in God in personal, community, and world life. Moreover, religious institute regulates the relationship between the adherents of religion and their relationship with their religious leaders in the framework of religiosity appreciation together. Based on this explanation, it is known that the religiosity referred to in this study is that religious life includes dogmas, rituals, morals, and institutions.

Thus, Hindu Culture and Religion are related to cultural systems that were born from understandings of Hinduism especially those that develop in Bali, whether it is the culture and religion in the context of religious literature or community life.

\section{RESULTS AND DISCUSSION \\ Barong and Rangda}

Etymologically, the word barong can be found in Old Javanese, namely barway, baroy: bear; honey bear (Zoetmulder, 2006: 112). The word barway is often found in combination with katasigha, and thus becoming sigha barway or siyabarway.

In line with this, Gautama (2007: 58) defines the word Barong in the Dictionary of the Balinese Language as a manifestation of animal mythology as a symbol of truth to fight destructive forces. Barong has many 
kinds such as barong bangkalin the form of large male pigs; barong bangkung in the form of sow; barong kět/kěkět/kěkek as the embodiment of the Banaspati Raja; barong landing in the form of a large tall human, in which the man is called Jero Gede with a creepy black face, while the woman is called Jero Luh with a white face which is rather cute.

However, the word Barong in Bali is not always used to mention the mythological animal figure but is also used to refer to other figures.

The word rangda etymologically comes from the word randa in Old Javanese, interpreted as a widow or a woman separated from her husband due to divorce or death (Zoetmulder, 2016: 918). But in fact the word Rangda is rarely used to refer to the sesuhunan that is worshipped. Rather, it is usually referred to as Ratu Ayu, Ratu sesuhunan and so on.

Barong in the Balinese cultural system and Hindu religion is divided into several types based on its forms; (1) Barong Ket-ket. This type of Barong is often called with another name such as Barong Ket, Barong Rentet, or Barong Ketet. This form of barong is a repertoire of lion, a mythological animal; (2) Barong Bangkal. This barong is a barong in the form of an old pig, (3) Barong Asu. The word asu is a delicate Balinese language which means 'dog'. Lexically, asu also means dog. Its face does resemble a dog's head; (4) Barong Macan. This barong is a barong with tapel of tiger which is assumed to be based on tantri stories; (5) Barong Gajah. This barong is in the shape of an Elephant; (6) Barong Sampi. This barong is in the form of a cow; (7) Barong Landung. This barong is in the form of a large tall human, a man called Jro Gede and a woman called Jro Luh; (8) Barong Brutuk. This barong is in the village of Trunyan, Kintamani, Bangli. The tapel from this Barong resembles a giant as a symbol of the warriors of Dewa Ratu Pancering Jagat Mahadewa from Penalaman temple; (9) Barong Blas-Blasan. This barong is also called Kedong Barong or Barong Nongkling.
This type of barong is a wayang wong show whose dancers use a mask accompanied with batel bebarongan music; (10) Barong Gambrongan. This type of barong is rarely found, but Van Dat Tuuk's research once found him in the Sayan area, Gianyar; (11) Barong Singa; (12) Barong Sae; (13) Barong Kambing; (14) Barong Jaran; (15) Barong Menjangan; and (16) Barong Dawangdawang. This barong is a variation of Barong Landung in the Tabanan area where the mask is in the form of very large giant.

Types of Rangda can also be distinguished based on face shape or prerai as follows: (1) Form of Nyinga. This shape is seen more in model of the tapel which is used to resemble a lion whose face is slightly protruding forward (munju). This form has a general trait of being fierce and savage; (2) Nyeleme form. This form is more like a human's face which is slightly widened. This form has an authoritative and haunted character; and (3) the Giant Form. This shape is more like a horrifying giant that we commonly see.

Barong and and Rangda arethe sacred pratima to Hindus. However, the object which was profane in the first place does not immediately become sacred. Barong and Rangda which have not passed through the sacralisation procession are just ordinary objects with different treatment with other objects. Therefore, there is a ceremonial procession with the ceremony that must be carried out to make Barong and Rangda a group of Hindus. The process of sacralisation in general is as follows.

The process of sacralisation has actually begun since determining its making. This is done in the determination of a good day of making both Barong and Rangda which are specifically chosen in accordance with the provisions of the Wariga. The next step is the choice of the material to be used. Generally the wood for making tapel is a special wood which is considered to have a magical power like Kayu pule, kapuh wood, jaran wood, cotton wood, teluh wood, or kepah wood. Coloring is also chosen specifically. The making of the framework and the selection 
of fur are also chosen according to the existing norms. After Barong or Rangda are finished, it is then continued with a procession of sacred ceremonies.

The sacralisation ceremony of Barong and Rangda is carried out through three main levels, namely the level of prayascita and melaspas, the level of praying or masupati, and masuci and ngerehin .

The level of prayascita and melaspas is a ceremony to cleanse leteh, papa, and klesa which are seen or unseen, especially related to the cleanliness of the materials or its making. The levels of ngatep and masupati is a procession of connecting tapel or punggelan with their bodies or other parts. The Masupati means carrying out a procession or reviving in which its essence is to transfer the desired forces into the object in pasupati. The level of masuci and ngrehin is the last stage of the ceremony which is intended to make Barong and Rangda holy and sacred. This ceremony is carried out in a place that is considered tenget which has magical powers such as temples and graves (Segara, 2000: 17-22).

\section{Barong and Rangda in Hindu Scriptures}

Hinduism is one of the oldest religions in the world that is still developing today. It was started from the archaeological discoveries about the civilization of Sindu river valley in Mahenjodaro and Harappah around 3000-2000SM, which described a religious system that became an embryo about the existence of Hinduism in India before the Vedic civilization began. There were special features of the worship system, such as worshiping the Mother Goddess, worshiping the Male God, worshiping the Lingga (Ithy_Phallicism), worshiping Trees and Animals, worshiping Arca (Iconism), and sacrificial ceremonies.

The worship of the Mother Goddess is one of the main characteristics in the civilization of the Sindhu river valley. Goddess in this case is described as a naked woman lying on her stomach with her legs astride; lying on her back, and standing up. Such images were obtained through findings which include seals, pottery, and amulets. The Mother Goddess is worshiped and is believed to be the power of women or shakti which is the source of all creation. Besides that, she is also believed to be a fertility goddess, ruler of plants, rulers and givers of magical powers (Phalgunadi, 2013: 8).

Furthermore, Phalgunadi (2013: 8) explained the worship of the Mother Goddessis performed together with worship of the Male God. The image of the Male God is found on one of the seals in the form of a carving of a human with two horns wearing a headband, surrounded by several animals. This form is considered a prototype of Lord Shiva. The form that is meditating or doing yoga is identified as Shiva Mahayogi or Shiva Yogeswara, while the presence of several animals surrounding it is identified with Shiva Pasupati or the ruling deity of wild animals. The most significant attributes of Shiva Pasupati are the triple face and holding the trident.This can be seen from the appearance of two horns and jata which are reminiscent of the trident concept.

The conception of worshiping Mother Goddess and Male God is a concept of divine duality which until now exists in Hinduism, namely God and his Shakti. This concept of worship also appeared in the Vedas in both Sruti and Smerti. In the Vedic books, gods and goddesses still have a special place in worship, as evidenced in the Rig's Wymes 1.89.4 and 4.17.4 which mention the existence of the God Dyaus and the Goddess Pertiwi who are believed to be the ancestors of the gods in the Vedas as follows.

tanno vato mayobhu vātu bheșajaì tanmātā prithivi tat pitā dyauh, tad grāvānah somasuto mayobhuvas tat aśwināśrṇutam dhiṣnya svasyate.

May air become a healing for us so that it becomes the Mother of the Earth and Father of the Sun. May the extracts of medicinal plants which are squeezed with grinding stones help to health. May the doctors and surgeons are adept at hearing our prayers. 
suviras te janitā manyata dyaur indrasya kartā svapastamo bhüt, ya im jajāna svaryaim suvajram anapacyutaì sadaso na bhūma.

You are the Descendant of your ancestors like the sun of her own self. May you a brilliantindividual become performer of the most outstanding work; You punish yourself with the strength of a steadfast will that cannot be destroyed for happiness. Indeed, you are supplied with great majesty.

The concept of worshiping Gods and their Shakti continues in the Smerti books, and is even more clearly visible in the religious traditions that develop. The Book of Smerti became an important source in the development of Hinduism in Indonesia, viewed from archaeological findings as well as manuscripts. This is recorded from the results of civilizations influenced by Hinduism from around the beginning of the century BC in Kalimantan to around the XIV century in Majapahit, East Java. Bali as a part of the development of Hinduism further reunited it in a cultural and religious frame that resulted in a tradition of worship of Barong and Rangda. In relation to this, the mysticism of Barong and Rangda can be traced through Hindu literature especially the Purana books and manuscripts documented in the manuscripts in Bali. Thus, this research will dig deeper into the concept of Barong and Rangda in two literary domains, namely Purana and Manuscripts (Lontar) as follows.

The Purana is a part of the Smerti book which contains ancient stories about the gods, the rsi and the kings. However, it is much deeper than just a story because it contains the teachings of religion, philosophy, history, sociology, politics and various other fields of knowledge. These books are references, encyclopedias or glossaries of Vedas. This can be understood, considering that the teachings of Hinduism contained in the Vedas are described again completely, especially concerning the theological issues of Hinduism in both Vaishnava and Shivaistic.

The Purana is divided into two major groups, namely the Maha Purana and Upa Purana. Maha Purana consists of 18 books, namely Brahma Purana, Padma Purana, Vayu Purana, Vishnu Purana, Bagavata Purana, Naradiya Purana, Markandeya Purana, Agni Purana, Bhavisya Purana, Brahma Vaivarta Purana, Linga Purana, Varaha Purana, Skanda Purana, Vandaana Purana , Kurma Purana, Matsya Purana, Garuda Purana, and Brahmanda Purana. Upa Purana also consists of 18 books, namely Sanatkumara Purana, Narasimha Purana, Naradiya Purana, Shiva Purana, Durvasa Purana, Kapila Purana, Manava Purana, Ushanas Purana, Varuna Purana, Kalika Purana, Samba Purana, Saura Purana, Aditya Purana, Maheshvara Purana, Devi Bagavata Purana, Vishnu-dhamottara Purana, Nilamata Purana.

The theological conception of the Vaishnese Padma Purana Book classified these books into three parts according to the Tri Guna Purusa Awata; (1) the Satwika Group dedicated to Lord Vishnu (godwho can deliver liberation) consisting of Vishnu Purana, Narada Purana, Bhagavata Purana, GarudaPurana, Padma Purana and Varaha Purana; (2) The Rajasika group dedicated to Lord Brahma (the qualification of passion which only leads to the attainment of Heaven) consisting of Brahmanda Purana, Brahmavaivarta Purana, Markandeya Purana, Bhavisya Purana, Vamana Purana, and Brahma Purana; and (3) The Tamasika Group dedicated to Lord Shiva (described as the ruling darkness of Hell) consisting of Matsya Purana, Linga Purana, Vayu Purana, Skanda Purana, and Agni Purana (Titib, 2004: 29).

Meanwhile, according to the Book of Skanda Purana which is more Shivaistic, the Maha Purana Book is grouped into five based on its worship characteristics, namely (1) The Purana Shivaistik Book consisting of Vayu Purana, Bhavisya Purana, Markandeya Purana, Lingga Purana, Matsya Purana, 
Kurma Purana, Vamana Purana , and Brahmanda Purana; (2) The Vishnusitic Purana book consisting of Vishnu Purana, Bhagavata Purana, Naradiya Purana, Garuda Purana; (3) The Brahmanistic Purana consisting of the Brahma Purana and Padma Purana; (4) The Agnistic Purana, namely Agni Purana, and (5) Savitritic Purana namely Brahmavaivarta (Titib, 2004: 30).

Besides the Maha Purana Book, there is also a book known as the Upa Purana Book as a small purana which is still considered as a continuation of the Maha Purana. Both the Maha Purana Book and the Upa Purana Book are books containing the teachings of Hinduism concerning the conception of worship of the gods. Lord Vishnu and Shiva become the main deities in several Purana books that are specifically worshiped, so that it seems as if there is a separation between Vaishnava books and those of a mystical nature. The source of Barong and Rangda conceptions in the religious system and Hindu culture can be traced in the Purana books which are both Shiva and Vaishnava which tell about Shiva with His Shakti.

The conception of Barong and Rangda is a repertoire of worship of Shiva with His Sakti in the Shivaistic conception. According to Santiko (1987: 1) the Purana books explain that Shakti Siwa has two aspects, namely śanta or śaumya (calm), and aspects of krodha or raudra (powerful) for the purpose of worshiping these two aspects of the goddess transformed into numerous goddesses. In other purana books, it is also explained about the existence of goddesses in three aspects, namely Sattvika (śanta), Rajasika (krodha) and Tamasika or krura (frightening, violent). Shiva as his partner will also adjust to the forms of his Sakti. We can see Shiva and his Shakti in the aspect of santa or śaumya from the manifestation of Shiva and Sati, Shiva with Parvati, Shiva with Gauri and others. We can also see Shiva with his Sakti in the aspect of krodha or anger and aspect of krura or frightening forms, such as Bairava with Bairavi, Mahakala with Mahakali, Shiva with Durga and other forms. Thus, Barong and Rangda are manifestations of both krodha and krura aspects of Shiva with his Sakti.

Aspects of krodha and krura can be traced through stories of the Purana, in both the Maha Purana and Upa Purana Shivaistic books such as Shiva Purana, Vayu Purana, Skanda Purana, Bagavata Purana, Markandeya Purana and others. These books in general tell about Shiva teachings with spiritual play from various aspects of Shiva and his Shakti.

The Purana books tell about Shiva's story in various names and forms. Shiva, in his various manifestations, has numerous names; it was mentioned that $\mathrm{He}$ has a thousand names or sahasra namah. Shiva's name is closely related to the character of worship and also the form taken in the story he plays. The aspect of Shiva's name is very diverse, each activity played is always associated with a different identity. From his activities, the Shiva aspect is also in line with the Shakti aspect, which has a calm and powerful aspect that is even horrible and creepy. Krodha or krura aspects from Shiva are depicted in Shivaistic purana stories such as Shiva as Shambu, Bairava, Rudra, Virabadra, Mahakala, Pasupata and so on.

According to Shiva Purana (Wijaya, 2014), Satarudra Samhita about various kinds of Shiva's reincarnations. The reincarnations of Shiva in each Kalpa is countless, but there are some things that can be described from several Kalpa in the Shiva Purana.

In Shiva's five reincarnations, there are five Shiva births as Rudra in several Kalpa. First,the form of Isana who masters and becomes connoisseurs of Prakerti, the form of Tatpurusa who controls all forms of objects of pleasure, the form of Aghora who masters and fulfils the principle of intelligence, the form of Wamadewa who becomes the ruler of all egos and dissolves in every activity endlessly, the form of Sadyojata who masters olfactory organs ( Wijaya, 2014: 5).

From Eight forms of Shiva, namely Sarva, Bhava, Rudra, Ugra, Bhima, Pasupata, Isana, and Mahadeva, Sarva 
represents a land element that holds the whole universe of both moving and nonmoving objects, Bhava represents the element of water that fills the entire universe, Ugra fills the inside and outside of the universe, Bhima represents elements that fulfill space, Pasupati as individual soul supporter is in charge of breaking all ties. Isana has power in heaven. Mahadeva represents the element of the moon which strengthens and brings feelings of satisfaction (Wijaya, 2014: 6).

It is explained again in the Shiva Purana about ten Shiva's incarnations with his Shakti; (1) Shiva as Mahakala with shakti Mahakali who bestows worldly pleasures; (2) Shiva as Tara with his divine power that bestows world happiness and liberation from slavery; (3) Shiva as Bala with the power of Sakti which bestows happiness on a virtue.

(4) Shiva as Srividyesa Sodasa with the essence of Shiva Sodasi that gives happiness to the devotion of world pleasure and liberation; (5) Shiva as Bairava with his Shakti Bairavi who bestows all his desires; (6) Shiva as Chinamastaka with his sincerity Dhumavati who grants all wishes; (7) Shiva as Dumavan with Shakti dhumavati who grants all the wishes of his good bhakta (8) Shiva as Bagala Muka with his Shakti Bagalamukhi (9) Shiva as Matanga with his Shakti Matangi who gives the results of all desires; and (10) Shiva as Kamala with his Shakti Kamalaa who is the protector of his bhakta.

For the purpose of worship, Shiva has various titles and forms. These forms are depicted through the stories of Shiva in various Kalpa. Thus, the number is very large and varied depending on the Kalpa, especially Shiva in great form which is found in purana books such as the following:

Shiva as Shambu. Shiva Shambu in Shiva Purana (Sanjaya, 2010: 201) is described as the highest Purusa who holds Mandakini (ganga) on his head and the crescent moon on his head, has three eyes, five faces, and ten hands, and also holds the trident. Shiva that has five heads, is also called Shiva Pancanana or Pancamukthi.
Shiva as Bairava; Shiva Bairava is one of the early manifestations of Shiva thatemerged when Vishnu and Brahma got involved in the dispute about the highest reality. Each one of them claimed to be the highest among the others, especially Brahma who mocked Rudra's arrival which made Shiva angry and created Bairava to punish Brahma by cutting off one of Brahma's heads. Bairava cut off one head from five Brahma heads using the tips of his nails. Bairava, also known as Kalabairava, is a creature depicted as horrible creature, capable of influencing nature. Kala was afraid of him since his anger would make him defeat shortsighted souls, and he is also known as eaters of the sins of devotees, and also as the destroyer of pride. The head of the Brahma which was turned into a symbol of redemption and brought by Bairava became a ritual related to the skull. The series of Brahma skulls adorned his neck (Wijaya, 2014: 33).

Shiva as Rudra; Rudra is Shiva's divine form in which Saguna manifests in the form of gods such as Brahma, Vishnu and Rudra. This manifestation was born from the Prakerti of Shiva; Brahma born from the right side, Vishnu from the left side, and Rudra from the middle (215). Vishnu appeared earlier at the discretion of Shiva, Brahma appeared through the lotus at Vishnu's navel, while Rudra appeared through Brahma's forehead. Although appearing through Brahma's eyebrows, Rudra was the essence of Shiva itself. Brahma, Vishnu and Rudra together with their siblings have their respective duties. Brahma as the creator, Vishnu as the keeper and Rudra as the destroyer.

Rudra is a form of Shiva who plays spiritual games with Brahma and Vishnu. Rudra lived alone on Mount Kailasa, and then married Sati, daughter of Daksa. Sati is the reincarnation of Durga which is the Shakti of Rudra himself. Shiva's illusion made Daksa disagree with Sati's marriage, making Shiva uninvited to big ceremonies that invite all the existing gods. Sati who was present on he own will did not accept the 
insult to Shiva, so she burned her own body with the power of her yogi.

Shiva as Virabhadra; Virabhadra is a manifestation of anger when losing Sati. Virabhadra was born from the arrogance of Rudra. Virabhadra was created from the strands of his hair into a terrifying creature; described as having a thousand heads, a thousand eyes, a thousand feet and a thousand spears, dressed in bloody tiger skin, carrying a burning arrow, and war ax. Virabhadra defeated all the gods and destroyed all the ceremonies held by the Daksa (Sanjaya, 2010: 279-280). Virabhadra beheaded Daksa, throwing him into the offering fire. Daksa was later forgiven, but his broken head was replaced with a goat's head.

Shiva as Pasupata; started with the story of Taraka Asura having three Sons named Tarakaksa, Vidyamali, and Kamalaksa, who then performed a tapa brata to Brahma and begged for the construction of three cities that had abundant wealth and were unmatched by the palace of the gods called Tripura. Tripura consists of three cities made of Gold, Silver and Steel (Sanjaya, 2011: 322). To eliminate the anger from the formation of Tripura and the killing all Asuras, the animalistic nature of the gods must be awakened. Thus, both the asura and the gods have animalistic nature. From that moment, the gods declared themselves as Pasu. This is meant that with animal nature, the gods can fight brutally. Since that time, Shiva became the ruler of the animals with the title Pasupati. With the power of arrows from Shiva Pasupati, Tripura and his Asura were destroyed.

From some portrayals of Shiva in various stories of Purana books in the form of krodha or krura, Shiva Pasupati is an important reference of the worship of Barong in Bali. It appears to have a bottom line about the concept of Shiva being the ruler of the animal described as Barong Lion. Pasupati appeared to conquer the anger of the crimes committed by the asura. Defeating the asura requires the animalistic nature from the gods as a form of rajasika.
The Barong embodiment which was identical with the Lion has the same bottom line as the ruler of the beast or as the king of the forest.

The manifestation of Sakti Shiva in the aspects of krodha or krura and various names and forms, such as Durga, Badrakali, Maha Kali, Kali, Kalika, Camunda is a terrible and frightening essence. In relation with the terrible creation of Shakti, the depictions of Dewi Kali, Maha Kali, Badrakali, Kalika are very identical to Rangda's depiction in Bali. They both have horrible, tiny, long tongue, and black hair.

Barong and Rangda in the Hindu literature in Indonesia are found in the lontar especially stored in Bali. The lontar as part of Hindu literature in the form of a free narrative tells the aspect of Shiva and Durga in various names and forms. Barong and Rangda are closely related to the shivaistic understanding developed all this time, and become the mythical aspects of the system of Shiva Tantra.

One of the inspirational stories of Barong and Rangda is found in Lontar Calonarang. The story in Lontar Calonarang started the story of Empu Beradah who lived in his hermitage, Lemah Tulis. He was very powerful especially in dealing with the Dharma. He was perfect in appreciation, and he knew the knowledge of the perfection of the world. The setting of this story was in Daha Kediri Kingdom with King Erlangga ruling peacefully, mastering the world with peace and prosperity, having noble virtues and tendency to imitate the priestly behavior.

It was also told about the story of a widow named Calonarang who lived in Girah. She had a daughter named Ratna Mangali, a woman who had a beautiful face like a palace gem yet no one wanted to propose to her because the public had heard that her mother had done horrible things. This situation hurt Calonarang, and she then worshiped Bhatari Bagavati in the grave followed with her students such as $\mathrm{Si}$ Weksirsa, Mahisawadana, Si Lendya, Si Lende, Si Lendi, Si Guyang, Si Larung, and $\mathrm{Si}$ Gandi in order to harm the whole kingdom. 
Rangda Girah danced together in the grave, which was soon joined by Paduka Batari Durga andhis numerous followers. Calonarang worshipped Batari Bagavati to beg for the destruction of the people around Daha. This Calonarang Story is related to the Durga Puja ceremony performed by Randa from Girah by worshipping Goddess Durga or Goddess Bagavati by dancing at midnight. Afterwards, many people died; sick in the morning, dead in the afternoon.

This action was known by King Erlangga who later sent his troops. This made Calonarang angry and performed a greater Durga Puja ceremony. Such considerable number of dead people because of the actions of Randa from Girah made King Erlangga send his prime minister to invite all Pastors, Rsi, bachelors, and the Guru to perform worship in search of clues. It was obtained from the worship that the one whocould take care of the kingdom and eliminate the defilements of the world and make prosperity is Empu Beradah from Lemah Tulis. Empu Beradah was then invited to the kingdom to protect the kingdom from the befallen plague.

To overcome the problems that befell the kingdom, Empu Beradah sent Mpu Kebo Bahula to propose to Ratna Manggali. Empu Bahula then proposed to Ratna Manggali on the instruction from Empu Beradah. Calonarang accepted the proposal and was happy to be a family of a priest from Lemah Tulis. After marriage, Empu Bahula finally knew that Calonarang went to the grave every night to create magic to spread the disease in order to destroy the kingdom. Ratna Mangali then instructed that the main book of Calonarang be taken to be discussed with empu Beradah.

Empu Beradah became very upset upon seeing the contents of Lipyakara belonging to Calonarang, the Book was actually the main literature which contained the path of goodness towards perfection, the top secret of the knowledge of the contents of that library. But it has been misused for world misery sorcery. Empu Beradah then went to the affected area and healed the sick and even revived the dead. When he arrived at Girah, he met Calonarang students in the Graveyard. Calonarang students asked the pastor to perform ruwat on them, but it must be done by Calonarang. Until finally Calonarang met Empu Beradah and asked him to show her the right way and to perform ruwat, but the Pastor refused. This is because Calonarang had done evil, caused the world's filth, caused misery in the world and killed the whole world, made people sick, and killed many people that she could not achieve liberation.

Rejection from Empu Beradah angered Calonarang who finally attacked him with her various powers yet she got lost and died. Empu Beradahthen revived her because he had not been able to learn about the science of deliverance in order to achieve liberation. After the death of Calonarang, Empu Beradah cleaned up all the defilements of the world caused byCalonarang. The kingdom returned to its peaceful state.

The story of Calonarang illustrates the existence of Shivaism which is described through the story about the grave or the place of freezing the corpse. The grave is a place of liberation from the Shivaistic system. It is an early sign of reaching Shiva. This is found in the story of Calonarang who made the Grave (the place of virtual freezing) from the Wife of Empu Beradah into a sacred place to meditate. Graves can also be used as places of worship rituals, as Calonarang did. Calonarang performed Durga Puja in the ruling aspect of all kinds of illnesses to defeat her enemy called the Goddess Bagavati.

The worship of Durga in the ruling aspect of the disease becomes inappropriate when used as a tool to hurt others, so it becomes a very big sin. The re-cleaning procession can be done by the priest to neutralize negative things by performing ruwatan (returning to the original form), just like Calonarang who was revived by Empu Beradah through death which was revived and died again as a process of reincarnation. This is the Shivaistic teaching contained in 
Calonarang's lontar which forms the basis of several performances of Calonarang.

Thus, Lontar of Calonarang shows the dualistic aspect of Goddess Durga as a protective source for the devotees, as well as fulfilling the wishes of her admirers in both positive and negative aspects. Positive aspects will bear positive results, and negative aspects will bear negative results. More detailed description of Barong and Rangda did not clearly appear in this lontar, but the story is often used as a setting for Barong and Rangda as the character of Rva Bhineda of God. The Bhineda Rva is a different dualist aspect but is a pairthat complement each other.

\section{Barong and Rangda in Balinese Culture}

Barong and Rangda have a special positionfor beingone of the forms of art that is included in the elements of Balinese culture. Barong and Rangda are tapelthat are usually danced in sacred or profane events. In general, Balinese dance can be categorized into three types of dance; wali, bebali, and balih-balihan. Wali dance is a sacred art which is usually performed in the temple. Bebali dance is a type of ceremonial art, usually performed in the central courtyard of the temple. This dance is both sacred and profane. Balih-balihan dance is a type of dance that is non-religious and tends to be entertaining, displayed on the front page or outside the temple.

Barong and Rangda dance in Balinese culture can be performed inside the temple or utama mandala, in the middle of temples or madya mandala, and outside temples or jaba mandalas. Thus, Barong and Rangda dances can be categorized into three types of dances; wali, bebali and balances. For this reason, this study places Barong and Rangda in Balinese culture in the three main points of discussion; Barong and Rangda as Wali dances, Barong and Rangda as Bebali dan Barong and Rangda dances as Bebalihbalihan dances as follows.

Wali dance is a type of sacred dance in Balinese culture. Sacred dance marks the existence of aspects of religious life that distinguish it from profane things. As revealed by Durkheim (2011: 72), the sacred is a fundamental religious characteristic compared to other supernatural elements. The sacred are things that are protected and isolated by prohibitions, while the profane are the things where the prohibition is applied and must remain left apart from the sacred. Beliefs, myths, dogmas, and legends are representations of sacred essence which put forth the rites as a rule of conduct which determines how humans must regulate their relations with sacred objects. For this reason, religion is an inseparable part in integrating society in addition to the values and norms based on the sacred aspects that build the system of values and norms.

Sacred dance is very sanctified by the Hindus and becomes an important part of a religious rite. Barong and Rangda dance is one of the sacred dances that are part of several Hindu religious ceremonies. In some temples which have sesuhunan in the form of pratima, Barong and Rangda dance will be performed when the piodalan is held. Barong and Rangda are usually danced with a series of stories from Calonarang.

Sacred processions about Barong and Rangda in Balinese society were also carried out on certain days like Galungan, Kuningan and Nyepi. During the Galungan ceremony, several temples that have Pratima in the form of Barong and Rangda will carry out the Melancaran Duwe ritual after the Galungan holiday. During melancaran, Barong and Rangda were taken around the neighborhood. The community around the place will welcome the offerings in front of their house in the form of bebantenan.

On the Kuningan and Nyepi days, the Grebeg ceremony is also held. Grebeg at the Kuningan holiday is held at the village intersection by escorting Barong and Rangda to carry out pecaruan.

Besides being sacred, Barong and Rangda dance can also be entertainment during Hindu religious ceremonies. There is a fairly classic play of magical drama in Balinese culture called performance of Calonarang. This performance is not only 
entertaining, but also contains magical elements. The performance of Calonarang drama has various versions in each performance even though it has the same bottom line as the main storyline from the story of Calonarang contained in written and oral traditions.

In Bebali performance, there is a variation in its performance flow, but there is a flow that is commonly used by referring to the story of Calonarang as shown below.

The beginning of Calonarang drama play is preceded by tetabuhan which plays bebarongan usually followed with the bapang Barong dance. Barong dance is played by two people with one at the front and one at the back. The Barong brought in a temple that carries out piodalan is usually the one to perform dancing at the opening ceremony.

The second scene is usually a sisya dance; a dance from the students of Calonarang who are all women. Calonarang's students still wear beautiful dress and make up. In the Lontar of Calonarang, there are eight students from Calonarang named $\mathrm{Si}$ Weksirsa, Mahisawadana, Si Lendya, Si Lende, Si Lendi, Si Guyang, Si Larung, and Si Gandi. However, in its performance, the dance can be pulled by eight or six people.

The Third scene is usually a depiction of the situation at Girah regarding Ratna Manggali as the daughter of Calonarang whom no one proposed to. This scene is played by several people, and is also added with comedy scenes to entertain as shown in the following picture. This scene continued with the emergence of Calonarang together with the people who was angry with the situation. She then invited all of her students to spread disease throughout the country. Calonarang is described as a middle-aged woman who is very powerful as a Durga worshipper for the purposes of spreading disease.

The Fourth Scene usually displays the figure of the minister from the Daha kingdom with his servants who were angry that Calonarang caused trouble by spreading disease throughout the country. Therefore, the Prime Minister of Daha Kingdom along with his troops attacked Calonarang at the request of King Erlangga. This scene is played by a minister who attacks Calonarang in Rangda's form. Calonarang's ability in the science of worshiping Durga made her as powerful as Durga so that she could defeat the prime minister of Daha kingdom.

The fifth scene usually displays the situation of the community affected by the diseases. However, there is an improvisation in the series of this performance which displays magical attractions by presenting Bangkai Matah, the corpses which becomes abet from challenging all expert of sorcery sciency to try to defeat him.

The sixth scene is the war of the minister from Daha Kingdom with Calonarang in the form of Rangda. This battle is illustrated with the stabbing scene of Rangda by a keris dancer who ganged up on Calonarang, but no one can stab her. Barong then came later to fight against Rangda. In that battle, no one is considered lost, both Barong and Rangda entered simultaneously. This is a depiction of the Shivaistic theological concept of Rva Bhineda; two different things but in pairs between men and women, Barong and Rangda, Purusa and Prakerti. This dualistic concept is the background of Barong and Rangda performance in Calonarang story or other stories.

Barong and Keris dance is a new dance drama art created from a sacred performance that becomes profane for public consumption. This can be seen from the many stage performances that are intended for tourists. Barong and Keris dance performances are held in several venues. There are 2 places in Denpasar, namely Barong and Uma Dewi Keris Dance and Barong and Sahadewa Keris Dance which are located on Jalan Waribang Denpasar. There are also Barong and Keris Dance in the Gianyar area, precisely in Batu Bulan Village where there are three stages for Barong and Keris Dance performance. 
Barong and Keris Dance adopted stories from Kunti Sraya story. Uma Dewi as a tourism agent for this art performance adopted story generally comtained in the sraya kunti performance. A synopsis of Barong and Keris Dance performances is given to visitors who want to watch. The show intended for tourism from various countries provides synopses in several languages such as French, English, Japanese, German, Korean and others.

The synopsis of Barong and Keris Dance by Uma Dewi contains a brief description of the story of Kunti Sraya which is illustrated through several scenes per round. The performance is opened with an opening song, Barong dance performance and an ape whichis in a thick forest, then continues with the emergence of three masked people who causes a scene by destroying the tranquility of the forest. Eventually the three men fights with an ape who manages to cut the nose of one of them.

The first round features two dancers as the followers of Rangda looking for the followers of Dewi Kunti. The followers of Goddess Kunti is on their way to meet the minister.

In the second round, the followers of Goddess Kunti arrived. One of Rangda's followers turned into a demon (a kind of rangda) and put an evil spirit into Dewi Kunti's followers which caused them to be angry. Both of them met the minister as shown in the picture below.

In the third round, Goddess Kunti and her son, Sahadeva, appeared. Dewi Kunti has promised Rangda to hand over Sahadewa as his victim. Actually Dewi Kunti did not have the heart to sacrifice her son to Rangda. But Satan (a kind of Rangda) is inside her, causing her to be angry and intended to sacrifice his son and ordersthe minister to throw Sahadeva into the forest. The Patih who was also influenced by an evil spirit went to the forest and tied him in front of Rangda.

In round four, Lord Shiva descended and gave eternity to Sahadeva. Rangda came and tried to tear and kill Sahadeva, but was unsuccessful because Sahadewa is immune to the Lord Shiva's bounty. Rangda then surrendered and begged to be saved to return to heaven. This request was fulfilled by Sahadev, and finally Rangda returned to Heaven.

The fifth round displays Kalika, a follower of Rangda, who came to Sahadeva for Ruwat but got rejected. The rejection made Kalika angry by turning herself into a Wild Boar, but Saha Dewa beat her. Kalika later turned into a bird, but also got defeated. Finally, the bird turns into Rangda. Since Rangda is so powerful, Sahadeva cannot kill him and finally Sahadeva turned into Barong. The power then turned equal which eventually made no winner.

\section{Barong and Rangda in the Hindu Religious System \\ a. Barong and Rangda As Shivaistic Teachings}

God is very difficult aspect to understand, so that in Hinduism is explained in various aspects of oneness. Even, great maharsi difficult to understand Him. This has been stated in Bhagavad Gita Sloka 2 as follows.

na me viduh sura-ganah prabhavam na maharsayah aham adir hi devanam maharsinam ca sarvasah

Neither the hosts of demigods nor the great sages know My origin or opulences, for, in every respect, I am the source of the demigods and sages

Barong and Rangda are descriptions of the theological essence in Shivaistic's teachings. This can be understood through Hindu scriptures such as the Purana and Itihasa, and through religion and manuscripts revealed in Indonesia. Theologically, Hindu portrays the divine aspect into two categories, namely God in the aspect of Nirguna Brahman and aspects of Saguna Brahman.

Nirguna Brahman is aspect of divinity that are difficult to understand, so 
that it is difficult to be made the object of concentration as has been stated in Bhagavad Gita XII Sloka 5 as follows.

\section{kleso 'dhikataras tesam \\ avyaktasakta-cetasam \\ avyakta hi gatir duhkham \\ dehavadbhir avapyate}

For those whose minds are attached to the unmanifested, impersonal feature of the Supreme, advancement is very troublesome. To make progress in that discipline is always difficult for those who are embodied.

Nirguna Brahman, also called The Brahman, is the Brahman free from guna. Nirguna Brahman can be interpreted as being infinite, unconditional and without character. $\mathrm{He}$ cannot be understood. $\mathrm{He}$ is without space, time, reason, and he is impersonal. $\mathrm{He}$ has no beginning, no end, he is everywhere (Tim, 2003: 49). Nirguna Brahman is a knowledge of God that is not accessible to humans. Donder (2009: 33) explained that God in this case has no particular form, has no name, unimaginable and unrecognizable because it is difficult to give attributes to the infinite. This is in line with what is revealed in the Shiva Purana (Wijaya, 2014: 270) that Nirguna Brahman is the origin of Shiva. The God of Nirguna exists before creation, in the midst of creation and the end of creation. In the concept of Shiva Tattva, this is called Paramashiva, namely Shiva without form, movement,beginning, ending, activities, and with perfection as explained in the following Tatwajana.

\footnotetext{
Paramaśiwatattwa ngaranya kasthitya bhatàra ring niûśkala, tan polah, tan limbak, tan laku, tan hili, tan pasangkan, tan paparan, tan pawitan, tan pawkasan, kewala sthiti, umidëng, humnëng langgëng juga sira, ibëk tang ràt kabeh de nira,
}

kakasut, kahmu kawyapaka kabeh, kang sapta bhuwana de nira, sapta pàtàla sundul wutuk sësëk pnuh lyab kang jagat de nira, tan kawënang linongan, tan kawënang tinambëhan, niûkàrya, niśprayojana juga sira, tan para wyapàra ring hala hayu, nirhuninga ta sira ika kabeh, mwang tan hana ngatitànàgata wartamàna ari sira, tan kahlêtan sira dening kala, rahina sàda juga sira, tan pakahilangan lan juga sira, nahan laksàna bhapàra Paramaśiwatattwa, yeka kasthityan bhatàra ring niśkala ika, sira ta bhatàra paramaśiwatattwa ngaranira.(Tatwajñàna. 3)

Paramaśiwatattwa, is Bhatàra in a formless, unmoved, immovable, not-flowing, notoriginating, not-directed, notstarting, not ending, only remaining firm, immovable, silent forever. He fulfilled the entire universe, covered it, supported it, and infiltrated the Sapta Bhuwana. The Sapta Pàla is fully fulfilled, there is no room left unfilled. $\mathrm{He}$ fulfilled the entire universe. He cannot be reduced cannot be disturbed by good and bad deeds. He cannot be known as a whole. And $\mathrm{He}$ knows the past, the future and the present. $\mathrm{He}$ is not hindered by time, always noon. There is nothing missing in Him. He is eternal. Such are the characteristics of Bhatara. 
The Nirguna Brahman aspect is explained further in the Upanishad books as follows.

Sad eva, saumya, idam agra àsid ekam evàditiyam, tadd haika àduh, asad evedam agra àsid ekam evàdvitiyam, tasmàd asatah saj jàyatah.(Chàndogya Upanishad.2.1)

At first, my child, there wasthis Only One personal, the one and only. Some people say that at first the one who was not this personal was the One and Only. From that impersonal, personal was created.

What is meant by personal in this case is $\mathrm{He}$ who is without restrictions. Before the realization of this universe, there was pure personal, One and Only; there are no two of this and no object other than this one. He does not have the existence that other beings have. $\mathrm{He}$ is in his own existence, all comes from Him and returns to Him.

Anejad ekam manaso javiyo nainad devà àpnuvanpùrvamarûat

tad dhàvato'nyan-atyeti
tisthat tasminn apo màtariúvà
dadhàti.

(Iśa Upanisad. 4)

The Àtman is without movement, one and more nimble than the mind. The Idriya cannot reach Him because He is always ahead of them. Even though $\mathrm{He}$ was silent, He defeated those who run. In Him the everpresent air supports all the activities of beings.

Tad ejati tan naijati tad dùre tad vad antike tad betweenasya sarvasya tad u sarvasyàsya bàhyatah (Iśa Upanisad. 5)

He moves and $\mathrm{He}$ does not move; $\mathrm{He}$ is far away and $\mathrm{He}$ is close, $\mathrm{He}$ dwells in everything and $\mathrm{He}$ is also beyond everything.

Yas tu sarvàni bhùtà àtmany evànupaúyati sarvabhùtesu càtmànam tato na vijugupsate (Iśa Upanisad. 6)

He who sees all beings in himself and himself in all beings, he does not see anything against such opinion.

Yasminsarvane bhùtàà àtmaivàbhd vijanatah tatra ko mohah kah úokah ekatvam anuspaúyatah. (Iśa Upanishad. 7)

For those who understand, all beings are united with their own àtman, then what sadness or illusion remains in those who understand this oneness.

Sa paryaàc chukram, akàyam, avranam, asnàviram, úuddham, apàpviddham

Kavir manisi, paribhùh, svayambhùh, yàthatathyato'rthàn vyadadhàc chàuvatibhyas sambhyàh.

(Iśa Upanishad. 8)

He has fulfilled everything; $\mathrm{He}$ is brilliant, without body, 
hand, without condition, pure, untouched by the evil one. $\mathrm{He}$ is a saint, a mind that is everywhere, exists because of himself, constantly dividing objects depending on their nature.

The aspect of Saguna Brahman is also called Apara Brahman; the concept of personal God, a god who has strength. He has limited power, which is involved with the experience and soul of individuals. He is Iswara. Apara Brahman is the Brahman who creates, maintains, and is a promoter of this world. He is present everywhere, omniscient, omnipotent, controlling the universe and the soul of the individuals. He is the ruler of karmic and moral law, and who harmonizes this world. He creates the tangible, the intangible, the temporary and the nontemporary, the unspecified and the definite, the conscious and the unconscious, the clear and the unclear as in the following sources.

Nihan Sadaúiwatattwa

ngaranya, wyàpàra ta

bhapàra Sadaúiwatattwa, wyàpàra ngaranya kinahanan sira de ning sarwañà mwang sarwakàryakàrta, sarwajñà sarwakàryakàrta ngaranya, anampih, hana padmàsana palungguhan bhapàra, caduúakti ngaranya, lwirnya, jñàna úakti, wibhuúakti, prabhuúakti, kriyaúakti, nahan tang singgah caduúakti ngaranya, jñànaúakti ngaranyatiga prabhedanya lwirnya : dùràdarúana, dùràúrawana, dùratmaka.

Dùràtmaka. Ngaranya ruméngö úabda adoh parëk duràtmaka ngaranya wruh ring àmbek ning adohaparëk, nahan tang sinangguh janaúakti ngaranya.
Wibhuúakti ngaranya tan kalangghanan ri sakeccha nira, kriyaúakti ngaranya sira humanak ikang ràt kabeh,nguniweh ikang watëk dewatà kabeh, kadyangganing brahmà, Vishnu, iswara, pañcaåsi, saptaåsi, dewaåsi, indra, yama, waruna, kubera, weúrawana, widhyàdhara, gandharwa, dànaw, daitya, rakûasa, bhùthayakûa, bhùta dëngën, bhùta kala, bhùta picasa, nguniwweh, ikang bhuwana, påthiwi, àpah teja, wàyu, àkàúa, candra, àditya, ikang kabeh. Kunag gawe bhapàra ssadaúiwatattwa ringsakalà, sang hyang úàstra, agama, aji, wedhya, tarka, wyàkaraóa, gaóita, ya tika gawe bhapàra sadaúiwatattwa , an sira paramaóa irikang ràt kabeh, sira maka drëwya irikang sakala niûkala, sira ta bhapàra àdipramàóa ngaranira, sira ta bhapàra jagatnàtha ngaranira, sira ta bhapàra makàróa ngaranira, sira ta batara parameúwara ngaranira. Sira ta bhapara mahulun ngaranira, sira tabhapàramaguru ngaranira, sira ta mangaran bhapàra waúa wasitwa, ika ta kabeh, siràgawe tan ginawang, sira ta wënang manghanàken, tan hana luwihana keúwaryanira, sira ta bhapàra guru ning guru, nahan lakûaóa bhapàra sadaúiwa.

Tattwajñàna, 4 
This is sadaúivatatva.

Sadaúivatattva Bhapàra is vyàpàra. Vyàpara means that $\mathrm{He}$ is fulfilled by sarvàjna (all-knowing) and sarvakàryakartà (allworking). Sarvajñà and sarvakàryakartà are padmàsana as bhapàra seat called Caduúakti, namely jñànaúakti, vibhùúakti, prabhuúakti, kriyaúakti. That is what is called the Caduúakti.

Jñàna is of three types, namely: duràdarúana, dùrràúravana, dùrràtmaka.

Duràdarúanais seeing the far and the near.Dùrrúúravanais hearing far and near sounds.Dùrràtmakais

knowing far and near actions. That is what is called jñànaúakti.Vibhúúaktiis no weakness in this entire universe. The Pabhuúakti cannot be hindered by everything $\mathrm{He}$ wants. Kriyaúakti is holding the whole universe especially all the gods, such as brahma, vishnu, isvara, pañcaåsi, saptaåsi, devaåsi, indra, yama, varuna, kubera, veúravana, vidhyddhara, gandharva, dànava, daitya, rakûasa, bhùthayakûa, bhùta dëngën, bhùta kala, bhùta picasa, so too with this world, påthiwi (land), apah (water), teja (light), wàyu (air), àkúa (ether), moon, planet. That is all the work of SadaúivatatvaBhapàra in the sakala realm is the Hyangúàsta àgama, the knowledge of spell (waidya) logic (tarka), grammar (wyakarana), arithmetic (gaóita).

Such is the work of Bhapàra Sadaúivatatva. He has power over all this world. It is he who possesses the seen and unseen world whose names arebhapàra Àdipramàóa, bhapàra jagatnàtha, bharaàra karaóa, bhapàra parameúvara, bhapàra guru, bhapàra mahulun, bhapàra vaúavaúiitva. He created but he himself was not created. $\mathrm{He}$ is the one who has the power to create and abolish. No one can defeat His power. He is Bhapàra, the Guru of the Guru. Such are the characteristics of Bhapàra Sadaúivatatva.

Sadaúiva is the Almighty God with various powers called caduúakti, namely jñànaúakti, vibhùúakti, prabhuúakti, kriyaúakti. Nothing is impossible for him.
Manomayo'yaý purusah, bhàh satyaá tasminn antarhrdayate yathà vrìthi và. $\mathrm{Sa}$ esa sarvasyeúànah, sarvasyàdhipatih, sarvam idam praûsàsti yad idàm kim ca. (Båahad-àranyaka Upanisad. V.6.1)
This shining creature which consists of thoughts is in the heart of rice or wheat, for instance. He is the master of everything, governs everything, regulates everything, whatever is there.

Thus confirmed in the Upanishad regarding the nature of Him as Sadaúiva, which include the thinkers of all, creators of all, govern all, and The Most perfect. 
Asann eva sa bhavati, asad

brahmeti veda cet, asti

brahmeti ced vedam santam

enam tato viduh.

Tasyaisa eva úàrira àtmà, yaá

pùrvasya, athàto

anuspraúnah, uta avidyàn

amuý lokam pretya kaúcana

gacchati $u$, àho vidvàn amu $\div$

lokam pretya, kaúcit

samaúnutà $u$;

so 'kàmayata, bahu syàm

prajàyeyeti, sa tapo'tapyata,

so tapas taptvà, idam sarvam

asåjata, yad idam kim ca, tat

srstvà tad evànupràvisat, tad

anupravisya sac tyac,

vijñanaý càvijñanaý ca,

satyam cànrtaý ca, satyam

abhavat, yad idam kim ca, tat

sat yam ity àcaksate.

(Taittiìya Upanisad.II.7.1)

There is no existence for someone who understands

Brahman as a non-personal. If someone understands

Brahman as what is now, people understand such thing as existence. This is indeed, the soul that is manifested from the former. The next question; do people not know that when separated from this life, they go to the world there? Or is there someone who understands that after leaving this world, he reaches that real world? He (the Most High Soul) wants something. Suppose I become numerous. Suppose I was born. He did tapa. After doing that, he created all of this, whatever is here. After creating this, he then entered it. After entering it he becomes the real and the outside, becomes measured and unmeasured, both whether it has basis or not, intelligence or not, right or not. As the real one, he becomes anything here. That is why he is real.

He is the cause of everything. He wants, he thinks and he creates. Tapa is the power of forming a creative, centered mind. $\mathrm{He}$ is transcendental.
İuàvasam idam sarvam yat
kim ca jagatyam jagat
tena tyatena bhuñjitha, mà
grdhah ksayasvid dhanam.
(İsa Upanisad. 1)

Know all this that everything that moves in this world, everything is wrapped up by God. Because of that, find your happiness in the deliverance and do not want something that is the right of others.

All objects that move and change are all wrapped up by Brahman. This world does not stand alone without the Brahman, but is entered by Him. The earth belongs to Brahman, but is entered by Him. Brahman is the Most High and absolute as the ruler. Brahman is everywhere. He is in the heart of all living things.

Descriptions from several sources, upanishad or lontar above, describe Shiva in the aspect of Saguna Brahman as a symbol of Cetana's second highest reality, namely Sadaúiva. Sadaúiva is an active, useful, shining God, consisting of elements of consciousness, having position and character. $\mathrm{He}$ covers everything. $\mathrm{He}$ is a creator, fighter, compassionate, shining, eternal, omniscient, and everywhere. For people who have no shelter, he is a brother, mother and 
father. He is the antidote to all pain and he frees people from the ties of punarbhava.

The aspect of Saguna Brahman as Shivatma can be understood by Shiva as the highest source of everything that exists through the duality of existence, namely as Purusa and Prakerti. As described in Shiva Purana (Wijaya, 2014: 217) Shiva has said to Brahma and Vishnu that they were born from His Prakerti. This shows Shiva as Purusa and at the same time as the source of all that exists. For example, Prakerti brings out the Satvam represented by Vishnu, Rajas represented by Brahma and Tamas represented by Rudra. Each of Brahma, Vishnu and Rudra has Shakti as a manifestation of their respective practices. Brahma with Sarasvati, Vishnu with Laksmi and Rudra with Uma. Brahma served as the creator, Vishnu as the preserver and Rudra as the destroyer. Rudra is the essence of Shiva itself with the task to destroy which can only be done by Shiva himself. Shiva and Rudra who are identically similar with Shiva make the Shivaistic system adore it to be the highest with Uma's shakti.

Rudra and Uma became important entities in Shivaistic worship by placing them as special ones. This is reflected in the Hindu worship system in Indonesia that has Shivaistic nuances by making Shiva and Uma the main idols. The virtue of worshiping Shiva and Uma is reflected in the rituals associated with Barong and Rangda, where Barong as Shiva's manifestation in the context of Banaspati Raja, Pasupata, ruler and protector of the region, and Rangda as the embodiment of Durga in the context of the rulers of disease, protection, fertility and well-being. The fundamental views of Barong and Rangda as Purusa and Prakerti are clearly illustrated in the Shivaistic literature stored in Indonesia.

\section{b. Barong and Rangda As Pratima}

The system of dogma in each religion will create a ritual system adopted by its adherents. The Hindus understand the nature of God as Nirguna Brahma and Saguna Brahman. God as Nirguna Brahman cannot be described or reached by humans, while God as Saguna Brahman is a God who can be described through agreed symbols.

The symbolic system of worship was carried out at the beginning of the Sindu river valley civilization in India on 3000SM2000SM. The cults were performed on the Mother Goddess and also the Male God, Lingga, and statues or arca (Phalgunadi, 2013: 11). This became an important feature in the civilization of the Sindu river valley which then continued to the Hindu worship system.

The worship using symbolic means in the form of Arca is also carried out to this day in Bali by calling it Pratima. Pratima is a symbolic object that portrays the omnipotence of God. These icons cannot suddenly change from being profane to being sacred; they have to go through certain processions as a form of sacralization.

The cult system in Bali is also identical with the use of symbols as a depiction of God's omnipotence in various aspects. The form of depiction which is called Citradevata can be of various kinds; in the form of human beings with various excesses, with four, eight, and twelve hands, three eyes, five heads, in the form of half men and women; in the form of animals, such as Barong Ket, Barong Bangkung, Eagle and others; in the form of half human, half animals like god Ganesha and Narasinga Awatara (Titib, 2001: 67).

Barong and Rangda are also one of the pratima worshiped by the Balinese Hindu community. Barong as embodiment of Lord Shiva while Rangda as the embodiment of the goddess Durga. Both are worshiped as a pair of symbols of God's omnipotence that are usually passed down in Temple.

\section{c. Barong and Rangda As a Dualistic System}

Barong and Rangda are dualist concepts in Bali Hinduism. Barong is identical to Purusa, while Rangda is identical to Prakerti. The concept of Barong and Rangda is identical with Samkhya thinking about the dualist principle. Samkhya 
states that this universe was born because of the existence of two elements called purusa and prakerti. Between purusa and prakerti are actually two principles which are both free and not bound to one another. Both are eternal elements, although in their creation these two principles unite. This is an important point in the system of Barong and Rangda as a dualist aspect because the substance of the entire universe consists of two different principles, namely purusa (spiritual principle) and prakerti (material principle).

Purusa is a spiritual principle. According to Samkhya, spirit is different from indriya, mind and reason. It is not the same as this world or other things. It is an awareness that has always been the subject of knowledge and has never been the object of knowledge. Purusa is an eternal consciousness that experiences no change, no cause, and it permeates everything but is free from all the bonds and influences of this world. For this reason, it is argued that the universe exists for the sake of purusa, like a bed that is not for itself but for people who sleep on it, that is Purusa. That the deliverance desired by all humans is indeed the Purusa who gets that. According to the Samkhya, it is stated that Purusa is actually numerous and uncountable.

Prakerti is the material principle as the first cause of the universe which consists of material and psychological elements. The traits of Prakerti is eternal, only one, and unlimited. Samkhya proves the prakerti as follows: (1) That everything in this world is limited and the limited always depends on the unlimited, which is prakerti; (2) The objects in this world have certain general characteristics which cause their owners to be happy, difficult, and neutral. Because of that, all must have the same source of the three causes, and the source is prakerti; (3) All consequences has cause-effect. The activity that causes the development of this world certainly comes from a first cause, namely prakerti. (4) An effect cannot exist without a cause, therefore there is certainly a fundamental cause, namely prakerti; (5) The universe embodies a unity. The existence of one unit shows the existence of a unifying cause, namely prakerti.

Prakerti consists of triguna, namely sattvam, rajas and tamas. Triguna is the forces that make up the prakerti. According to Samkhya, the creation after purusa is related to prakerti, then this triguna is shaken and rajas begins to affect sattvam and tamas. From this triguna, the next evolution takes place in prakerti, which is Mahat/Buddhi, Ahamkara, Manas, Panca Buddhindriya, Panca Karmendriya, Panca Tan Matra, and Panca Mahabhuta. Thus, purusa and prakerti cannot be separated in the universe even though they are truly different to one another.

Purusa or spiritual principle is eternal, independent, numerous, uncountable, while prakerti or material principle consists of material and psychological (psychological) elements, only one, the first cause of the birth of the universe, unobserved but is clearly present.

Prakerti has tri guna (strength), namely (1) sattvam which is light and calm; (2) rajas which is a source of activity; and (3) tamas which is heavy, lazy, dark and ignorant (avidya). Before the creation took place, these two principles were equally pure, not affected by anything outside themselves. Even though in Samkhya theory of creation both elements met, it was unknown who exactly approached whom, and who influenced whom. However, it is possible that prakerti approached purusa because prakerti is active, whereas purusa only provides stimuli so that prakerti was willing to approach it, like a magnet that has an attraction for iron. This means that the meeting of these two elements is a "mandatory" thing for the sake of creation because without the presence of both, creation is not possible.

When the purusa met prakerti, the tri guna state is no longer balanced. Purusa was captured by prakerti and was held to be an individual spirit. In the development of this stage, sattvam appears to be more dominant than rajas and tamas so that the visible 
characteristics are things that are calm, bright, and illuminating. The result of the first evolution of prakerti is "Mahat" as the cosmic principle, said to be the seed of this world, and "Buddhi" as its psychological principle. Buddhism has virtues (dharma), knowledge (jnana), no passion (vairagya), and divinity (aiswarya). Buddhi has a skill called "viveka jnana", which is the ability to distinguish, consider and decide.

From Mahat (Buddhi), Ahamkara was born. Ahamkara is the principle of the individual which is also divided into two; the cosmic and psychological aspects. The cosmic aspect gives rise to the subject and object, while the psychological aspect creates "self-sense" or selfness or "ego". Ahamkara in Samkhya can be divided into three types, namely ahamkara si vaikerta (vaikarika), ahamkara si taijasa, and ahamkara si bhutadi. Ahamkara vaikerta is the ahamkara dominated by sattvam, ahamkara taijasa is the ahamkara dominated by rajas, and ahamkara bhutadi is the ahamkara dominated by tamas. Of the three, ahamkara taijasa (rajas) only serves to give power to sattvam and tamas for the next evolutionary purpose. At this stage, prakerti was further developed into two majors; namely psychological majors and physical major. Psychological evolution was dominated by sattvam and physical evolution was controlled by guna tamas. From sattvam, manas (mind), jnanendriya, and karmendriya were born, all of which are called eka dasendriya (eleven indriya), not senses instruments. Manas is the first psychological development, a tool that cooperates with the senses to observe reality outside of humans. Manas functions to guide the senses in dealing with objects and to continue the knowledge gained to ahamkara and buddhi, and otherwise to continue the decisions of Buddhist will to the five senses (buddhendriya). The second psychic development is the panca buddhendriya or the five jnanendriya, namely vision (caksuindriya), hearing (srotendriya), smell (ghranendriya), (rasendriya/jihvendriya), (tvakindriya). The third mental development is the five karmendriya, namely the power to speak (vakindriya), the power to dispose of waste (payuindriya), the power to catch (panendriya), the power to intercourse (upasthendriya), and the power to move (padendriya). Therefore, buddhindriya and karmendriya can be distinguished in that buddhindriya/jnanendriya is these senses related to knowledge or cognition, while karemendriya relates to activities. These forces are latent, meaning they may appear when dealing with real objects. For example, the power of hearing will only appear when there is a sound, sight if there is a form, and so on.

It has been mentioned above that physical development emerges from tamas. The first development is panca tan matra, which include the essence of form (rupa tanmatra), the essence of smell (gandha tanmatra), the essence of taste (rasa tanmatra), the essence of touch (sparsa tanmatra), and the essence of sound (sabda tanmatra). From these tan matra, harder elements emerged in the form of atoms (paramanu) called Panca Mahabhuta; sound produced akasa (ether); sound and touch produced vayu (air); sound, touch and color produced teja (rays/fire); sound, touch, color, and taste produced apah (water); and sound, touch, color, taste, and smell produced prthivi (soil). Finally, from these coarse elements, the development of the universe and its contents and the evolution of prakerti have stopped because the five maha bhuta have not delivered new principles. The differences in the universe occur solely due to the compilation of elements of the five mahabhuta, not the new principle, because the elements remain in what have been produced.

It is understood that the whole evolution that occurs in the creation according to Samkhya is carried out by prakerti and will return to prakerti. Meanwhile,the shackled purusa does not carry out any activities in the practice because no space is given to move. Finally, before purusa is aware of itself, that $\mathrm{He}$ is 
truly free, then $\mathrm{He}$ will forever remain shackled by prakerti and follow the cycle of birth-life-death, samsara. The ultimate goal of sankhya is to release the purusa from the ties of prakerti. This is only possible when humans are free from the shackles of avidya (ignorance), asmita (bad behavior), body (greedy lust), dvesa (hatred) and abhinivesa (fear) so that they can distinguish between spirit and not spirit (vivekajnana = knowledge to differ ). Since purusa is consciousness, and the subject of knowledge, the purusa which is liberated is the purusa who knows itself is purusa.

\section{CONCLUSION}

Based on the analysis of the previous chapters, the results of this study can be summarized as follows.

First, the Barong and Rangda conception is in the Hindu Literature, namely the Purana books and also the books that have been adapted in the Old Javanese literature. In the Purana books, Barong and Rangda can be associated with the manifestation of Shiva and Durga in the aspect of Krodha. This aspect is the highest form of the omnipotence of God that gives grace and protection to the devotees. Moreover, terrible forms are not a threat to worshipers, but are a guarantee for the protection of the devotees.

Second, Balinese culture places Barong and Rangda in the sacred and profane realms. Barong and Rangda become Wali dance during religious rituals, which is danced in connection with certain ceremonies at a temple. Barong and Rangda become Bebali dance since it can be entertainment during Hindu religious ceremonies. Besides their sacredness, the dance of Barong and Rangda can also be an entertainment during Hindu religious ceremonies such as the performance of Calonarang Drama. Barong and Rangda become Balih-balihan dance, which is a special dance to be exhibited. At present, there are a number of special places such asBarong show and Keris Dance.
Third, Hindu Religious System explains Barong and Rangda as the concept of Shivaistic divine teaching which explains the dualistic aspects of God as Purusa and Prakerti as a whole unit. Barong and Rangda are worshipped as Pratima, the embodiment of the omnipotence of God, the protector and the giver of all the welfare of life in the world.

\section{BIBLIOGRAPHY}

Dana, I Wayan. 2011. Paruman Barong di Pura Puncak Padang Dawa Baturiti Tabanan: Persepektif Kajian Budaya. Yogyakarta: BP ISI Yogyakarta.

Donder, I Ketut. 2009. Teologi: Memasuki Gerbang Ilmu Pengetahuan Ilmiah tentang Tuhan Paradigma Sanatana Dharma. Surabaya: Paramita.

Durkheim, Emile. 2011. The Elementary Forms of The Relegios Life, Sejarah Bentuk-Bnetuk Agama Yang Paling Dasar. Jogjakarta: IRCiSoD.

Gautama, Wayan Budha dan Sariani, Ni Wayan. 2009. Kamus Bahasa Bali;

Bali-Indonesia. Surabaya: Paramita

Gautama. Wayan Budha. 2009. Katuturaning

Barong Swari Lan Dalang (Asal Mula Lahirnya Barong dan Dalang. Surabaya: Paramita.

Hardjana, AM, 1993. Penghayatan Agama: Yang Otentik dan Tidak Otentik. Yogyakarta : Kanisius.

Hardjana, AM, 2005. Religiusitas, Agama dan Spiritual. Yogyakarta : Kanisius.

Koentjaraningrat. 2005. Pengantar Antropologi, Pokok-Pokok Etnografi II. Jakarta : Renika Cipta.

Koentjaraningrat. 2009. Pengantar Ilmu Antropologi. Jakarta: Renika Cipta.

Mulyana, Slamet, 2005. Menuju Puncak Kemegahan (Sejarah Kerajaan Majapahit). Yogyakarta : LKIS.

Palgunadhi, I Gusti Putu. 2013. Sekilas Sejarah Evolusi Agama Hindu. Denpasar : Widya Dharma.

Paramita, IGA Dewi. 2012. Kurma Purana. Surabaya: Paramita.

Radhakrisnan, S. 1989. Upanisad Utama Jilid I, Jakarta: Yayasan Dharma Sarathi. 
Radhakrisnan, S. 1998. Upanisad Utama Jilid II, Jakarta: Yayasan Dharma Sarathi.

Sabri, Muhammad. 2010. Lonceng Kematian Mistisisme Agama. Yogyakarta: Resist Book.

Sanjaya, Gede Oka. 2001. Garuda Purana. Surabaya: Paramita.

Sanjaya. 2010. Siva Purana. Vol. I. Surabaya: Paramita.

Sanjaya. Gede Oka. 2001. Narada Purana. Surabaya: Paramita.

Sanjaya. Gede Oka. 2001. Siva Purana. Surabaya: Paramita.

Sanjaya. Gede Oka. 2001.Agni Purana. Surabaya: Paramita.

Sanjaya. Gede Oka. 2002. Bhavisya Purana. Surabaya: Paramita.

Sanjaya. Gede Oka. 2002. Vayu Purana. Surabaya: Paramita.

Santi, Ni Komang Ari. 2013. Menguak Misteri Pementasan Barong dan Rangda dari Sudut Pandang Saint. (cosmies Fertilization). Surabaya: Paramita.

Santika,Hariati.1987. Kedudukan Bhatari Durga di Jawa pada Abad X-XV Masehi. Jakarta: Universitas Indonesia.
Segara, Nyoman Yoga. 2000. Mengenal Barong dan Rangda. Surabaya: Paramita.

Segara, I Nyoman Yoga. 2017. Hindu Spiritual Groups In Indonesia And Their Active Roles In Maintaining Harmony. Semarang: Analisa Journal of Social Science and Religion Volume 02 Number 02 December 2017.

Suprayoga, Imam dan Tabroni. 2001. Metodelogi Penelitian Sosial Agama. Bandung: Rosdakarya.

Swandiana, Jro Mangku Oka. 2008. Barong Landung, Bernuansa: Magis Religius. Surabaya: Paramita.

Tim Penyusun, 2011. Kamus Besar Bahasa Indonesia, Pusat Bahasa. Jakarta: PT Gramedia Pustaka Utama.

Tim Penyusun. 2003. Siwatattwa. Denpasar: Pemerintah Provinsi Bali.

Titib, I Made. 2001. Teologi dan SimbolSimbol dalam Agama Hindu. Surabaya: Paramita.

Wijaya, Prima Surya. 2014. Siva Purana Vol.III. Surabaya: Paramita.

Zoetmulder, P.J. dan Robson, S.O. 2006. Kamus Jawa Kuna-Indonesia. Jakarta: $\quad$ PT Gramedi 